\title{
Household arrangements of elderly persons in Brazil: analyses based on the national household survey sample (2009)
}

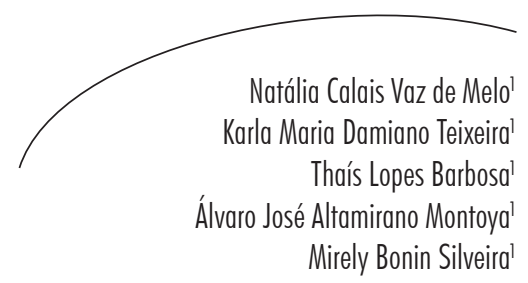

Abstract

Introduction: Increased longevity and, consequently, a rise in the number of elderly persons in Brazil, has an effect on different sectors, especially family living arrangements. Objective: To analyze the socioeconomic profile of the family living arrangements of the elderly using PNAD micro-data (2009). Method: A quantitative, descriptive, cross-sectional study using PNAD micro-data (2009) was performed. The elderly family living arrangements that constituted households in Brazil were analyzed. Results: The results indicated that the most representative arrangement was a couple who lived with their children and other relatives, followed by single parent units and couples with children. The head of household in most of the arrangements featuring a couple with children and other relatives was a man, while in one-person, single parent and mixed arrangements the head of household was more likely to be a woman. Conclusion: Decisions regarding the type of family arrangement are attributed not only to the elderly individual and his or her family, but are the result of historical, sociocultural, political, economic and demographic factors, which may positive or negatively interfere with the quality of life of elderly persons.

1 Universidade Federal de Viçosa, Departamento de Economia Doméstica. Viçosa, MG, Brasil.

The data analyzed in this study is taken from the "Arranjos domiciliares de idosos no Brasil: Análises a partir da Pesquisa Nacional por Amostra de Domicílios (1989, 1999 e 2009)" (Household Arrangements of Elderly Persons in Brazil: An analysis based on the National Household Sample Survey (1989, 1999 and 2009), financed by the Conselho Nacional de Desenvolvimento Científico e Tecnológico (National Council for Scientific and Technological Development) (CNPq) and by the Fundação de Amparo à Pesquisa do Estado de Minas Gerais (Foundation for Research Support of the State of Minas Gerais) (Fapemig).

Key words: Elderly; Family Characteristics; Demografic Aging.
Natália Calais Vaz de Melo Thaís Lopes Barbosa' Mirely Bonin Silveira' 


\section{INTRODUCTION}

The global phenomenon of the growth of the elderly population is a global phenomenon of increasing significance in both developed and developing countries. ${ }^{1}$

Brazil is undergoing a process of significant population aging. In the 1940s and 1960s, the death rate in Brazil declined while the birth rate remained constant. In the second half of the 1960s there was a significant reduction in the birth rate, resulting in large differences in the age distribution of the Brazilian population. The same phenomenon took place in the majority of countries of Latin America and the Developing World. ${ }^{2}$

The growth of the elderly population has occurred in different forms in various parts of the world. While in developed countries this process has occurred in a slower, more gradual manner, in developing countries it has taken place more quickly, with the society in question often unprepared to deal with it. As a result, despite being a global phenomenon, population aging differs between countries, states, regions and cities, as the manner in which it occurs depends on the socioeconomic, historic and political situation of each location. ${ }^{3}$

Projections suggest that in 2020 Brazil will have 30 million elderly people, the sixth biggest such population in the world. ${ }^{4}$ The elderly population is growing by around 650,000 each year, with elderly women being more numerous than elderly men. In the year $2000,55.1 \%$ of the elderly population was composed of women, and for every 100 elderly women, there were 81.6 elderly men. ${ }^{5}$ The situation remained the same in 2010, with women representing $55.8 \%$ of the elderly population of Brazil. ${ }^{6}$ This reality can be explained by the fact that women live, on average, eight years longer than men. ${ }^{6}$

Since the 1950s the elderly population, especially elderly women, has been concentrated in the urban areas of the country. The number of elderly people living in urban areas grew significantly, however, in proportion to the rest of the population, between 1950 and $1970 .^{7}$

Some studies ${ }^{8}$ have considered that the place where an elderly person lives can influence his or her living arrangements. Urban areas, due to processes of modernization and urbanization, can generate a sense of individualism among people, affecting traditional customs and values. As such, it has become more acceptable for elderly people who live in urban areas to choose to live alone, resulting in new household arrangements.

In Brazil, the household arrangements of the elderly have been changing over the years due to sociodemographic and structural alterations and changes in values. The decision regarding the type of household arrangement of the elderly is not solely the choice of the elderly person and his or her family, but a reflection of a series of historic, sociocultural, political, economic and demographic factors, which can positively or negatively affect an individual's life.

Analysis of the data of the $2010^{9}$ Demographic Census shows that between 2000 and 2010 there was an increase in the number of people living alone in Brazil, with the mean percentage rising from $8.6 \%$ to $12.1 \%$. Such an increase was a largely urban tendency. Additionally, changes in cultural behavior, and the increase in marital separations and life expectancy have contributed to this statistic, making elderly persons choose to live alone.

Some studies ${ }^{7}$ have shown that one explanation for this is that, faced with widowhood or separation, women prefer to be the head of single parent families, to live in the homes of their children, alone or with relatives. Men, meanwhile, seem to prefer to rebuild their own family through new relationships, and when unable to do this, would rather live with children or relatives than to live alone, displaying, therefore, a greater degree of dependence. 
In terms of household arrangements, the number of households whose head is an elderly person has increased since 1980. The number of households with elderly persons in the role of parent and/or mother or father-in-law and living with other relatives, has declined from $4.5 \%$ to $3.3 \%$ since the same year. Families with elderly members have a different structure, and are generally older, in a more advanced cycle of life, and have more women as heads of households than in families without elderly persons. ${ }^{10}$

In terms of income, there has been a drastic reduction in the number of low income elderly persons. In 1993 the number of elderly persons with a family income of up to half of the minimum salary was $21.5 \%$, while in 2003 , this percentage fell to $12.5 \%{ }^{.11}$

In light of the above, the main investigative question the present study proposed to answer was: what are the different household arrangements in which elderly persons are inserted, and what are their socioeconomic characteristics?

In this way, this study aimed to analyze the socioeconomic profile of different household arrangements in Brazil, based on microdata from the Pesquisa Nacional por Amostra de Domicílios (PNAD) (the National Household Sample Survey) of 2009 .

\section{METHOD}

The present cross-sectional study was quantitative and descriptive in nature, and employed secondary data.

The secondary data was taken from the 2009 PNAD, carried out by the Instituto Brasileiro de Geografia e Estatística (the Brazilian Institute of Geography and Statistics) (IBGE). This database was chosen due to the large quantity of information it contains regarding households, taken from the population at large, which allowed the identification and analysis of the profile of the different household arrangements in which the elderly persons were inserted.

The aim of the PNAD is to investigate, annually, the general characteristics of the population, such as: education, work, earnings and housing, as well as characteristics of migration, birth rates, marital status, health, food safety and other factors. It is produced with varying frequency, depending on the information needs of the country. These statistics represent, over the 44 years of the study, an important tool for the formulation, validation and evaluation of policies aimed at socioeconomic development and to improve the living conditions of the Brazilian people. ${ }^{12}$

The universe analyzed was the living arrangements of elderly persons resident in domestic units and living in all the regions of Brazil.

PNAD 2009 microdata was selected for this study. This data was extracted and statistically analyzed, using the STATA 12.0 (Data Analysis and Statistical Software) software program.

To delineate the socioeconomic profile of the different domestic arrangements in which the elderly persons were inserted, an exploratory analysis of the data was performed to clearly characterize the population being studied, so that clustering characteristics could be identified. ${ }^{13}$

With the aim of describing the panorama of the income of elderly persons in Brazil, the Gini index,${ }^{14}$ which consists of measuring the degree of income concentration in a particular group, identifying the difference in income between its richest and poorest members, was calculated. Generally the Gini coefficient varies from zero to one, in which zero represents a situation of equality, or in other words, where everyone earns the same, while a score of one represents the other extreme, in which one person earns all the wealth.

The results obtained in relation to the earnings of the elderly were shown in a Lorenz curve, which 
is a graphic, analytical tool which allows income distribution to be analyzed, as well as allowing the ordering of distribution of earnings in relation to well-being. The Lorenz curve shows the relationship between the proportion of people with an income elevated to a determined value, and the proportion of income received by these people. ${ }^{15}$

In addition to this characterization of household arrangements, regression least squared regression was performed, for the determinants of the monthly income of the families being studied. The linear regression model of monthly income is given by the following equation:

$Y_{i}=\beta_{0}+\beta_{1}$ gender $+\beta_{\underline{j}} j o b+\beta_{3}$ ethn $+\beta_{4} e d u c+$ $\beta_{5}$ urban $+\beta_{6}$ members $+\beta_{\text {fge }}+\varepsilon i$, with gender being a categorical variable with a value of 1 for male heads of household and 0 for female heads of households; job being 1 when the head of household was in work in the referenced week and 2 when he or she was not in work; educ represents the years of formal education of the head of household; urban is 1 when the household forms part of the urban area and 0 when it relates to a rural residence; members represents the maximum number of family members who lived in the house; and; $\varepsilon$ is the term of regression error.

Finally, to compare the possible factors that influenced the income of the household arrangements, a linear regression model was used. This is a statistical, descriptive and inferential technique, which consists of analyzing the relationship between a dependent variable and a set of independent variables. ${ }^{16}$

In accordance with the Ethics Research Committee of the Universidade Federal de Viçosa (the Federal University of Viçosa), as the data, while relating to humans, was taken from a public access database, it was not necessary to submit the project for approval.

\section{RESULTS AND DISCUSSION}

Socioeconomic profile of the elderly persons

Of the 191.8 million people that PNAD (2009) surveyed, 20.2 million were aged 60 or older, representing $10.54 \%$ of the total population. The mean age of the elderly persons was 70.7 years $( \pm 7.7)$, with a minimum age of 61 and a maximum age of 112 years, with $75 \%$ aged 76 years or less and $10 \%$ aged 82 years or more. There was a predominance of females, of whom there were 11.3 million $(55.87 \%)$, which can be explained by the fact that the life expectancy of women is greater, and by the high mortality of Brazilian men of all age groups, which results in a lower number of elderly men. ${ }^{4}$

The educational level of the elderly persons remained low, with $61.01 \%$ ( $\mathrm{n}=12.3$ million) having only a primary level education. A total of $9.55 \%$ ( $n=1.9$ million) had a high school education; $6.12 \%$ ( $\mathrm{n}=1.2$ million), a university education; and only $0.42 \%$ ( $\mathrm{n}=0.08$ million), a postgraduate education.

In terms of the ethnicity of the elderly persons, it was noted that the majority were Caucasian (55.60\%; $\mathrm{n}=11.2$ million); $35.97 \%$ ( $\mathrm{n}=7.2$ million), mixed-race; $7.17 \%$ ( $\mathrm{n}=1.4$ million), Afro-Brazilian; $0.93 \%$ ( $\mathrm{n}=0.188$ million) Asian-Brazilian; and $0.29 \%$ ( $\mathrm{n}=0.059$ million) indigenous.

Figure 1 shows the geographic distribution of people aged 60 years or over according to Brazilian region and state. A greater concentration of elderly persons was found in the southeast, which was home to $47.2 \%$ ( $\mathrm{n}=9.5$ million) of the population of this age group. Contrastingly, the states with the lowest presence of old people in order of importance were: Amazonas, Distrito Federal (the Federal District), Sergipe, Tocantins, Rondônia, Acre, Amapá, and Roraima. Taken together, these states represent less than $5 \%$ of the national elderly population. 


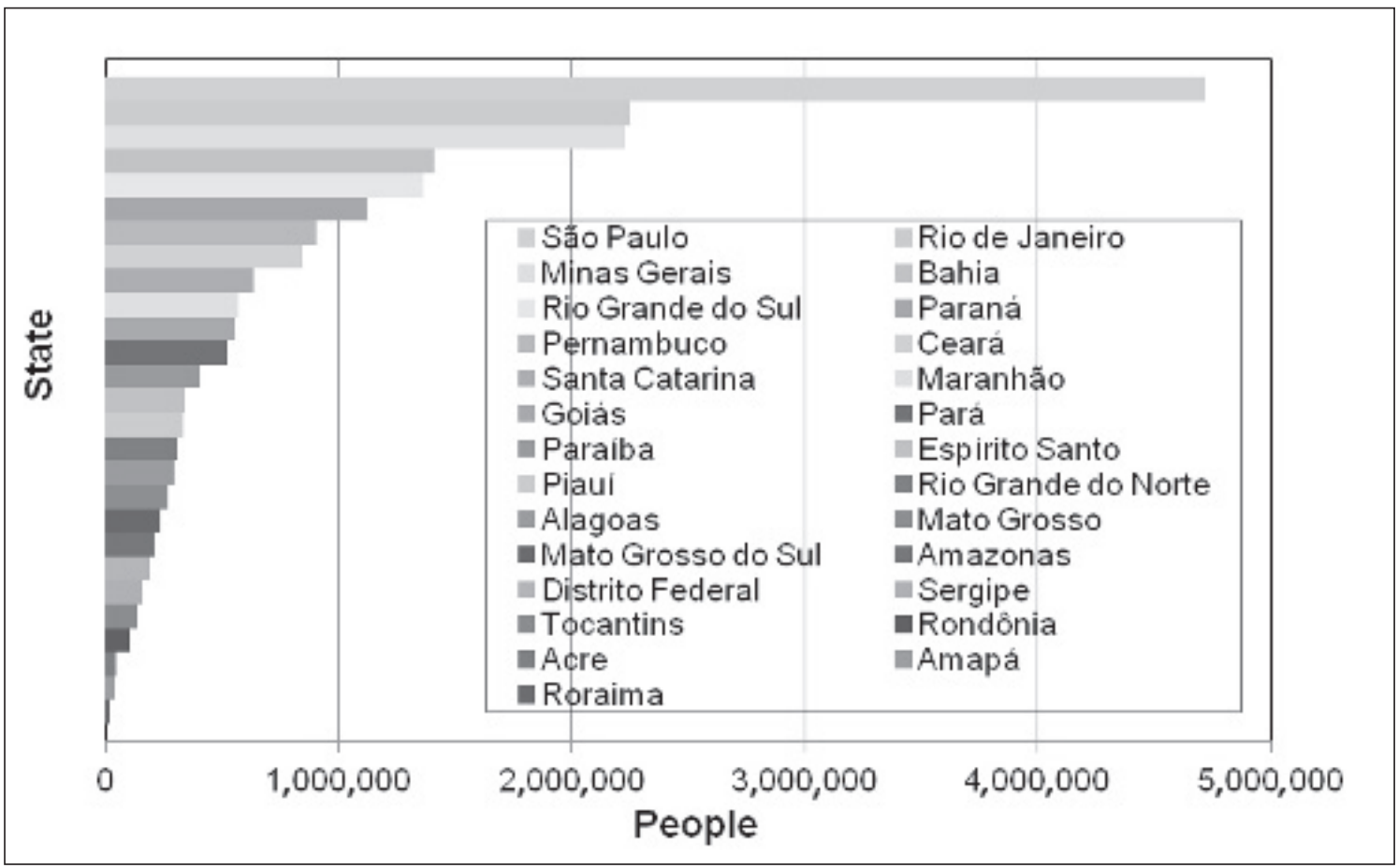

Source: PNAD (2009)/IBGE.

Figure 1. Elderly people by state. Brazil, 2009.

Additionally, it was noted that $83.16 \%$ ( $\mathrm{n}=16.8$ million) of elderly people resided in an urban zone, characterizing this segment of the population as urbanized, which could be explained by the fact that this region has the greatest population density, as well as offering better conditions and services to meet the needs of this age group. Data from the $2000^{5}$ Demographic Census showed that living in the city can be a good choice for the elderly, as they can live closer to their children and access the services they require.

\section{Characterization of household arrangements of elderly persons}

The 2009 PNAD classification of household arrangements, which does not include, for example, single person arrangements, was restrictive for the purposes of the present study. It was therefore decided to create a new classification of household arrangements. This empirical classification, which corresponds principally to the possibilities/ limitations of the data base, was as follows: Lives Alone*; Mixed**, Couple without Children***; Couple that Lives with their Children****; Couple without Children or Relatives*****; Couple that Lives with Children and Relatives******; and Single Parent*******.

*Household unit where the elderly person lives alone.

**Household unit comprised of the reference person and other relatives.

$* * *$ Household unit in which the reference person resides only with his or her spouse.

****Household unit in which the reference person lives with his or her spouse and child.

$* * * * *$ Household unit consisting of the reference person, his or her spouse, and other relatives.

******Household unit comprising the reference person, his or her spouse, child, and other relatives.

*******Household unit where the reference person lives with his or her child and/or other relatives.

In all family arrangements at least one of its members was classified as elderly. The reference person was considered the person responsible for the household. The spouse was the resident who lived conjugally with the reference person. The child was the person who was a childstepchild, adopted or foster child of the reference person and/ or his or her spouse. Other relatives were considered individual(s) who was or were not related to the reference person or his or her spouse. This classification was made from the aggregation of the "other relative", "non-blood relative", "lodger", "domestic worker" and "relative of domestic worker" that the National Household Survey (2009) uses to classify the inhabitants of household units. 
The sample employed cut-off points based on monthly per capita income, as the extreme values of this variable significantly altered its central tendency measurements, and as such, the results of the analysis. For the cut-off, a monthly per capita income of $\mathrm{R} \$ 0.00$ was taken as the minimum criteria and an income of $\mathrm{R} \$ 65,000.00$ was used as the maximum criteria.

According to the classification of household arrangements used in this study, in 2009, 41.38 million people lived with elderly persons, representing 14.16 million families.
In the distribution shown in Figure 2, the most frequent arrangement was couples who lived with children and other relatives, followed, in order of frequency, by single-parent arrangements and couples with children. It is worth noting that the lives alone arrangement was the penultimate in order of importance in the distribution of living arrangements. However, while in the case of elderly persons the number of single person households was not expressive in relation to the other domestic arrangements, the number of elderly persons living alone is increasing. ${ }^{17}$

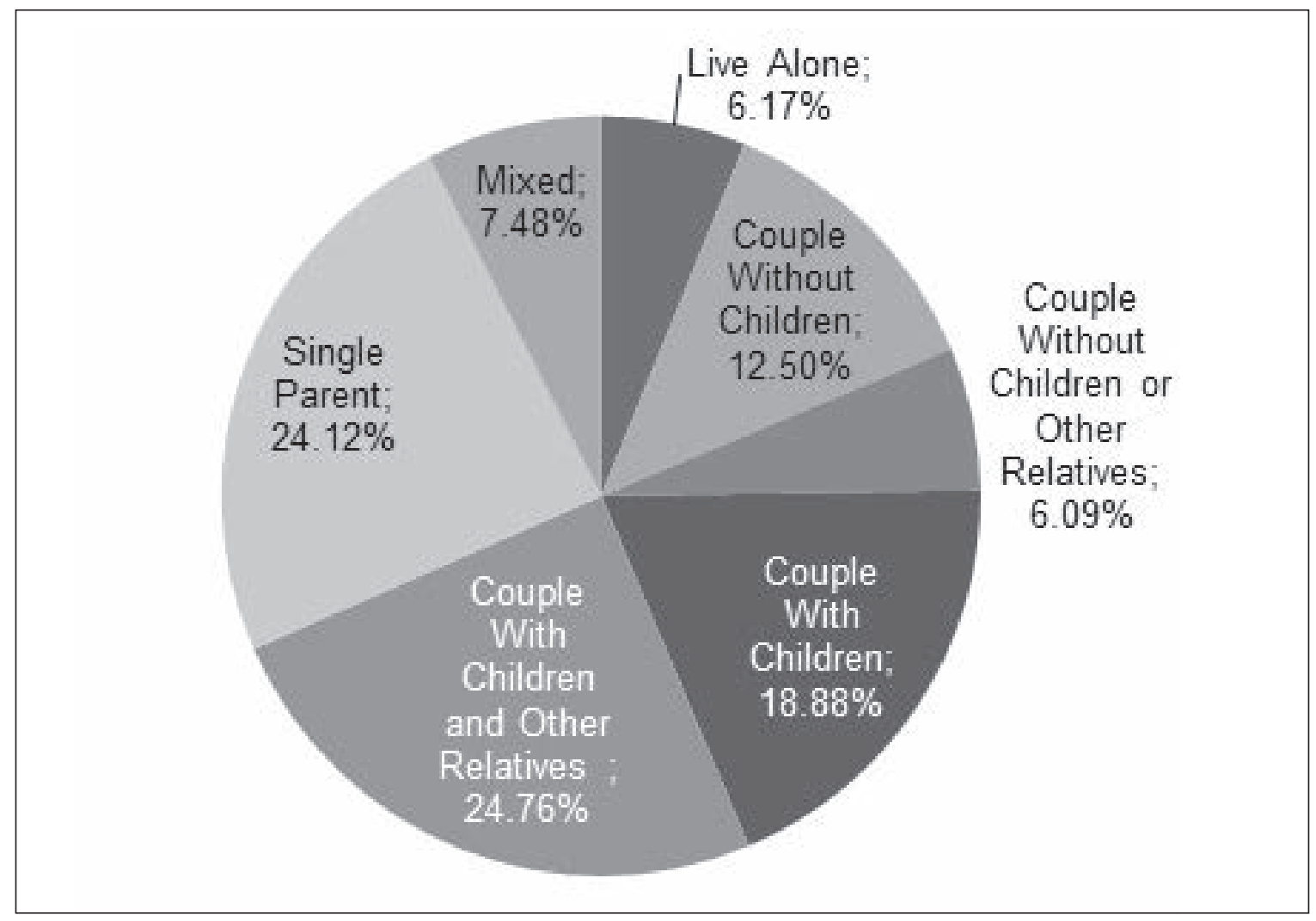

Figure 2. Distribution of household arrangements of elderly persons. Brazil, 2009.

Of the families analyzed, $84.21 \%(\mathrm{n}=11.93$ million) had an elderly person as their head and, of these, $57.24 \%$ ( $n=6.82$ million) had men as their heads. This distribution may be due to social gender stereotypes, based on distinct and hierarchical roles within the family, ${ }^{18}$ which can influence the perception of the elderly persons and other family members in terms of the head of the family.
This situation changes for the arrangement lives alone, where female heads of households are more frequent, representing $66.8 \%(\mathrm{n}=1.70$ million) of the total. In mixed and single parent arrangements there were also more female heads $(84.7 \% ; n=676,000$ and $82.6 \% ; n=2.16$ million, respectively), as, in many cases, with faced with widowhood, women prefer to live alone rather than remarry or become heads of households. 
Some studies 19 consider that "widowhood is the predominant marital state among elderly women". This data has also been found by other studies, ${ }^{20-22}$ which affirm that the increase in the life expectancy of women has created more widows and, subsequently, an increase in single person female households.
In terms of the geographical distribution of the household arrangements, the greatest concentration was found in the southeast, $(46.72 \% ; n=6.61$ million), followed by the northeast $(26.61 \% ; n=3.7$ million), south (15.38\%; $\mathrm{n}=2.17$ million), north $(5.59 \% ; \mathrm{n}=0.80$ million) and mid-west (5.59\%; $\mathrm{n}=0.79$ million), as can be seen in figure 3 .

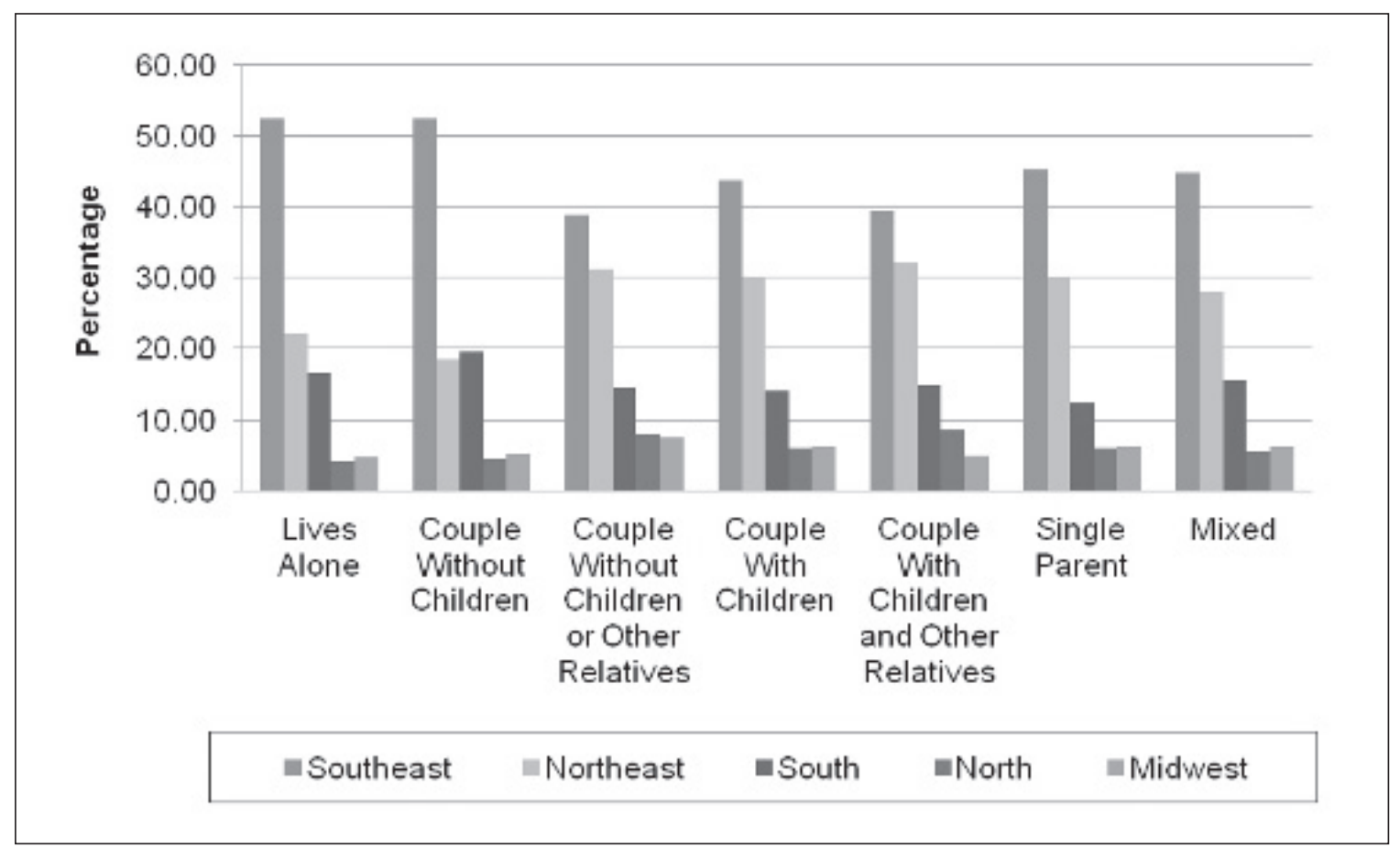

Figure 3. Percentage distribution of domestic arrangements by region. Brazil, 2009.

Of the households studied, the majority, $83.53 \%$ $(\mathrm{n}=11.83$ million), lived in the urban areas of Brazil.

In relation to marital status, it was noted that the majority of elderly individuals were married $(53.80 \% ; n=9,995,157)$, followed by widowed $(29.89 \%$; $\mathrm{n}=5,553,077)$, single $(10.05 \%$; $\mathrm{n}=1,867,524)$, divorced $(3.16 \% ; \mathrm{n}=586,476)$ and separated $(3.10 \% ; \mathrm{n}=586,476)$ elderly persons.

In terms of economic activity, only $27.6 \%$ $(\mathrm{n}=5.11$ million) of the elderly persons were in work, and, of these, $64.3 \%$ ( $\mathrm{n}=3.29$ million) were men. Even when able to retire, many elderly persons prefer to remain in active employment. According to some studies ${ }^{23}$ the productive capacity of elderly persons in Brazil is growing, and has contributed to an increase in active aging. This change is a reflection of the improvement in the quality of life of the population, especially the older population, as in recent decades there has been a significant growth in the number of elderly persons and increased access to health services.

The distribution of income among elderly people in work was unequal, which was congruent with the estimates of national inequality in income distribution. In this sense, the Gini coefficient for monthly salary calculated was 0.63 (figure 4 ), with the coefficient for the monthly salary distribution of women slightly inferior (0.61).

In addition, the mean monthly salary of elderly men $(\mathrm{R} \$ 1,319.00)$ was significantly greater than that of elderly women ( $\mathrm{R} \$ 801.00)$, resulting in an unequal participation in overall income. Women were responsible for only $20 \%$ of the total salary earnings of the study. 


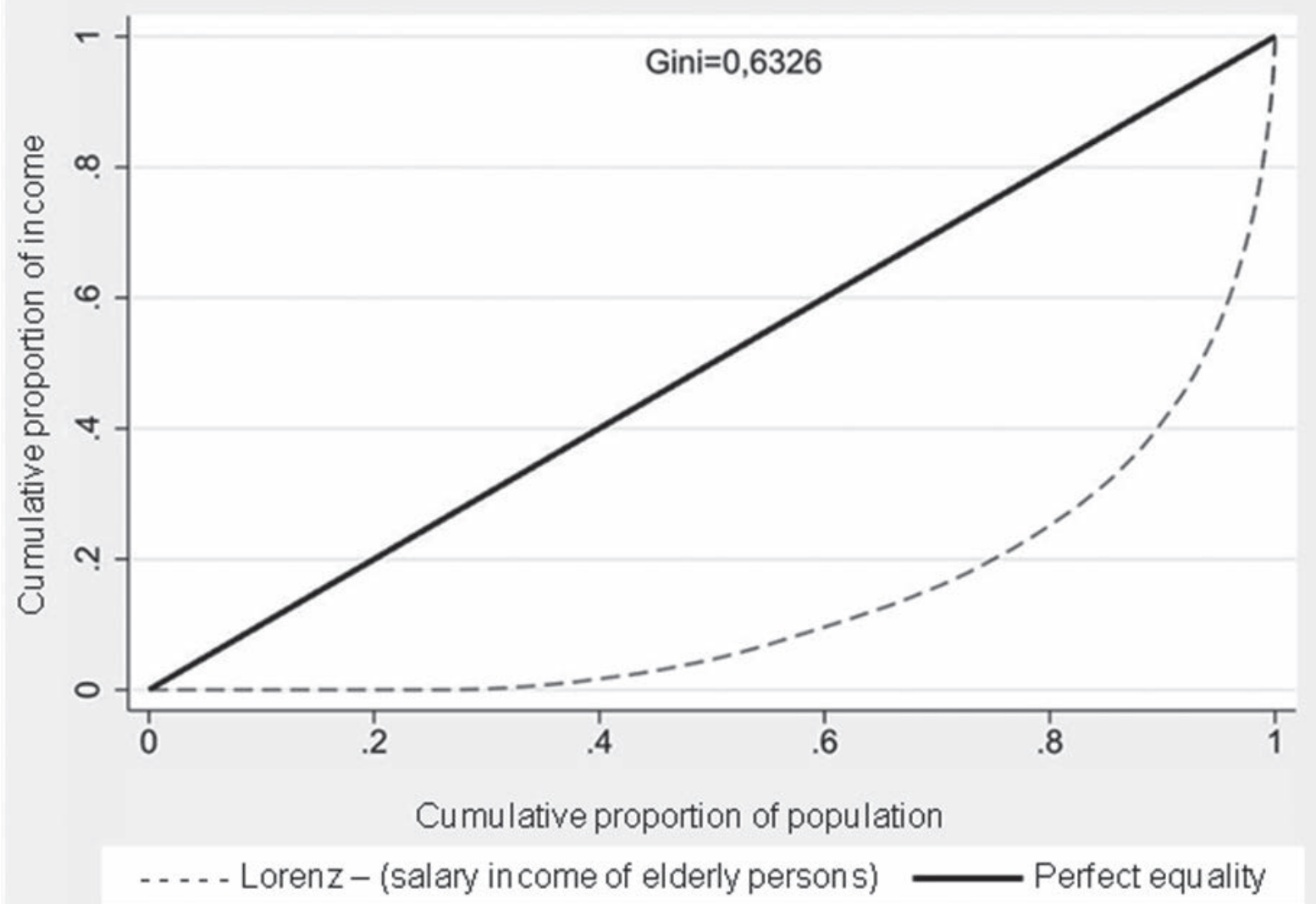

Figure 4. Lorenz Curve of salary income of elderly persons in work. Brazil, 2009.

Table 1. Factors that influence monthly income of domestic units. Brazil, 2009.

\begin{tabular}{lc} 
Number of observations $=11,303,324$ & $\mathrm{R}^{2}=0.1589$ \\
\hline Variables & Coefficients \\
\hline Gender & $420.43^{*}$ \\
In work & $-673.92^{*}$ \\
Ethnicity ${ }^{\mathrm{a} /}$ & \\
$\quad$ Afro-Brazilian & $-1.032 .59^{*}$ \\
Asian-Brazilian & $750.53^{*}$ \\
Mixed Race & $-922.06^{*}$ \\
$\quad$ Indigenous & $-709.23^{*}$ \\
Education & $399.15^{*}$ \\
Urban & $1.067 .64^{*}$ \\
Number of members & $172.89^{*}$ \\
Age & $28.87^{*}$ \\
\hline
\end{tabular}

$*$ Significance of $5 \% ;{ }^{a}=$ Base condition for comparison was Caucasian ( $0=$ Caucasian) 
With a coefficient of determination $\left(\mathrm{R}^{2}\right)$ of $15.89 \%$ (table 1), the household arrangements studied that were headed by men had, in 2009, a mean income that was $\mathrm{R} \$ 420.00$ greater than the monthly income of those headed by women, or in other words, there was inequality between the genders. Contrastingly, the results of regression analysis showed that elderly persons not in work received on average $\mathrm{R} \$ 673.00$ less than elderly persons who were working during the reference week. This inequality in income has a direct influence on the consumption of goods and services, as elderly persons with a higher income have greater spending power, ${ }^{24}$ which can have an effect on their quality of life.

In terms of ethnicity, with the exception of Asian-Brazilians, the monthly income of household arrangements with a Caucasian head of household was significantly higher than those with an AfroBrazilian ( $\mathrm{R} \$ 1,032.00)$, mixed race $(\mathrm{R} \$ 922.00)$ or indigenous $(\mathrm{R} \$ 709,00)$ head of household.

It was also found that each additional year of schooling represented an increase of $\mathrm{R} \$ 399.00$ in the monthly income of households. The fact that the elderly persons lived in urban zones was an important determinant for income, since the coefficient of this independent variable was $\mathrm{R} \$ 1,067.00$ higher due to living in this type of area. Contrastingly, the number of members of a household and age had little influence on monthly income, with an increase of $\mathrm{R} \$ 172.00$ for each extra member of the household and $\mathrm{R} \$ 28.00$ more for each additional year of age.

As such, the importance for the study was to identify each type of household arrangement in which the elderly persons were inserted. The description of the profile of all of the constituent members of the household arrangements follows below.

\section{Couple without children}

The mean age of heads of households of couples without children was 69.3 years $( \pm 8.13)$, with a minimum age of 19 and a maximum age of 102 . The majority of heads of households were men $(87.24 \%$; $\mathrm{n}=2,256,123)$. In relation to ethnicity, $62.35 \%$ $(n=1,612,452)$ of heads of households considered themselves to be Caucasian; $30.87 \%(n=798,314)$, mixed race; 5.64\% ( $\mathrm{n}=145,818)$, Afro-Brazilian; $0.90 \%(\mathrm{n}=23,299)$, Asian-Brazilian; and $0.24 \%$ $(n=6,225)$, indigenous. The level of education of the majority of the heads of households was low, with $77 \%(\mathrm{n}=1,659,113)$ having completed only primary education.

The mean age of the spouses in this type of household arrangement was 65.4 years $( \pm 9.09)$, with the minimum 17 and the maximum 95 years. Of these, $87.12 \%(\mathrm{n}=2,235.558)$ were women. In terms of ethnicity, $62.70 \%(n=1,621,421)$ considered themselves Caucasian; 31.02\% ( $\mathrm{n}=802,335)$, mixed race; 5.25\% ( $\mathrm{n}=134,381)$, Afro-Brazilian; 0.94\% $(\mathrm{n}=24,296)$, Asian-Brazilian; and $0.14 \%(\mathrm{n}=3,712)$, indigenous. The majority of spouses also had a low educational level, with $77.54 \%(n=1,636,413)$ having only a primary education.

\section{Mixed}

In the mixed arrangement, the mean age of the head of household was 62.6 years $( \pm 15.5)$, with a minimum age of 15 and a maximum age of 102 , with $73.26 \%$ being women $(n=885,281)$. In relation to the ethnicity of heads of household, $52.37 \%$ considered themselves Caucasian $(\mathrm{n}=632,839)$; $37.30 \%$, mixed race $(\mathrm{n}=450,701) ; 8.91 \%(\mathrm{n}=107,718)$, Afro-Brazilian; 1.16\% ( $\mathrm{n}=14,067)$, Asian-Brazilian; $0.18 \%(\mathrm{n}=2,124)$, indigenous; and $0.08 \%(\mathrm{n}=968)$ did not declare their ethnicity. The majority of heads of households had only primary level education $(58.63 \%$; $n=573,609)$; with $22.82 \%$ $(\mathrm{n}=223,263)$ having a secondary level education; $17.66 \%(\mathrm{n}=172,747)$, higher education; and $0.90 \%$ $(\mathrm{n}=8,780)$ postgraduate education.

The mean age of the other relatives was 43.2 $( \pm 28.05)$, with a minimum of 0 and a maximum of 106 , with $58.80 \%(n=1,109,812)$ of the other relatives being female. In relation to the ethnicity of the other relatives, $48.67 \%$ considered themselves Caucasian ( $\mathrm{n}=918,623) ; 42.40 \%(\mathrm{n}=800,233)$, 
mixed race; 7.51\% ( $\mathrm{n}=141,661)$, Afro-Brazilian; $1.23 \%(\mathrm{n}=23,134)$, Asian-Brazilian; $0.16 \%$ $(\mathrm{n}=3,102)$, indigenous; and $0.04 \%(\mathrm{n}=665) \mathrm{did}$ not declare their ethnicity. The majority had only a primary level education $(61.07 \% ; n=660,491)$; $28.49 \%$ ( $n=308,160)$, a secondary level education; $10.11 \%(\mathrm{n}=109,343)$, a higher education; and $0.33 \%$ $(\mathrm{n}=3,547)$, a postgraduate education.

\section{Couple with children}

In the couple with children arrangement, the mean age of the heads of households was 66.7 years $( \pm 7.55)$, with a minimum of 29 and a maximum of 106 , and with $87.75 \%(\mathrm{n}=1,908,995)$ of these being men. In relation to ethnicity, $52.44 \%(n=1,140,869)$ considered themselves Caucasian; $40.15 \%$ ( $n=873,544)$, mixed race; $6.33 \%$ ( $n=137,633)$, Afro-Brazilian; 0.91\% ( $n=19,690)$, Asian-Brazilian; e $0.17 \%$ ( $n=3,793)$, indigenous. In terms of educational level, $73.92 \%(n=1,324,493)$ had a primary level education; $15.63 \%(\mathrm{n}=280,120)$, a secondary level education; $9.60 \%(\mathrm{n}=172,079)$, a higher education; and only $0.84 \%(\mathrm{n}=15,002)$, a postgraduate education.

The mean age of the spouses was 60.5 years $( \pm 10.34)$, with a minimum of 21 and a maximum of 93 years. Women represented $87.75 \%(n=1,908,985)$ of the spouses. In terms of ethnicity, $53.19 \%(\mathrm{n}=1,157,172)$ of the spouses said they were Caucasian; 39.99\% ( $\mathrm{n}=869,991)$, mixed race; 5.67\% ( $\mathrm{n}=123,382)$, Afro-Brazilian; $0.88 \%(\mathrm{n}=19,137)$, Asian-Brazilian; and $0.27 \%$ $(\mathrm{n}=5,825)$, indigenous. In terms of educational level, the majority of spouses had only a primary level education $(73.93 \% ; \mathrm{n}=1,322,744)$.

The mean age of the children in the couple with children arrangement was 26.5 years $( \pm 10.81)$, with a minimum of 0 and a maximum of 62 , with $59.79 \%$ $(n=2,068,957)$ of the children being male. In terms of ethnicity, $50.78 \%(\mathrm{n}=1,757,236)$ considered themselves Caucasian; $43.80 \%$ ( $n=1,515,848)$, said they were mixed race; $4.49 \%(\mathrm{n}=155,250)$, AfroBrazilian; 0.74\% ( $\mathrm{n}=25.719)$, Asian-Brazilian; 0.16\% $(\mathrm{n}=5.502)$, indigenous; and $0.03 \%(\mathrm{n}=968)$ did not declare their ethnicity. The educational level of these children can be considered higher than that of their parents: $41.95 \%(n=915,005)$ had a secondary level education; $34.95 \%(n=762,291)$, a primary level education; $22.38 \%(\mathrm{n}=488,248)$, a higher education; and $0.72 \%(n=15,597)$, a postgraduate education.

\section{Couples without children or relatives}

In the arrangement of couples without children or relatives, the mean age of the heads of households was 63.3 years $( \pm 12.93)$, with a minimum age of 20 years and a maximum age of 102 years. A total of $83.52 \%$ of the heads were male ( $\mathrm{n}=619,360)$. In terms of ethnicity, $48.59 \%$ ( $n=360,325)$ described themselves as Caucasian; 42.34\% ( $\mathrm{n}=313.988)$, mixed race; 8.09\% ( $\mathrm{n}=60.023)$, Afro-Brazilian; $0.72 \%(\mathrm{n}=5.339)$, Asian-Brazilian; and $0.26 \%$ $(\mathrm{n}=1.928)$, indigenous. The level of education of the heads of household was low, with $75.21 \%$ $(n=444,292)$ having only a primary level education.

Remaining with this household arrangement, the mean age of spouses was 59.9 years $( \pm 13.31)$, with a minimum age of 16 and a maximum age of 100 years, and $83.70 \%(\mathrm{n}=620,733)$ of spouses were women. In relation to ethnicity, $49.43 \%$ $(\mathrm{n}=366,586)$ considered themselves Caucasian; $42.39 \%(\mathrm{n}=314,372)$, mixed race; $6.79 \%(\mathrm{n}=50,388)$, Afro-Brazilian; 0.87\% ( $\mathrm{n}=6.448)$, Asian-Brazilian; and $0.52 \%(n=3.835)$, indigenous. The level of education of the spouses was also low, with $72.60 \%$ $(\mathrm{n}=434,610)$ having only a primary level education.

The mean age of the other relatives was 33.3 years $( \pm 28.81)$, with a minimum of 0 and a maximum of 112 years, and $52.44 \%(n=544.483)$ being women. In terms of ethnicity, $47.83 \%$ $(n=496,558)$ considered themselves Caucasian; $44.77 \%(\mathrm{n}=464,874)$, mixed race; $6.77 \%(\mathrm{n}=70,304)$, Afro-Brazilian; 0.50\% ( $\mathrm{n}=5,206)$, Asian-Brazilian; and $0.13 \%(\mathrm{n}=1,328)$, indigenous. In terms of educational level, $64.90 \%(\mathrm{n}=248,995)$ had only a primary level education. 
Couples with children and relatives

In the household arrangement couples with children and parents, the mean age of the heads of households was 58.5 years $( \pm 14.44)$, with a minimum of 18 years and a maximum of 102 years, and $83.93 \%(n=1,638,340)$ being men. In terms of ethnicity, $46.01 \%(\mathrm{n}=898,159)$ considered themselves Caucasian; 43.58\% $(\mathrm{n}=850,695)$, mixed race; 9.31\% ( $\mathrm{n}=181,682)$, Afro-Brazilian; $0.82 \%(\mathrm{n}=15.958)$, Asian-Brazilian; and $0.28 \%$ $(\mathrm{n}=5.550)$, indigenous. With regard to educational level, $69.45 \%(\mathrm{n}=1,129,579)$ had a primary level education; $20.97 \%$ ( $n=341,016)$, a secondary level education; 9.15\% ( $\mathrm{n}=148,802)$, a higher education; and only $0.44 \%(\mathrm{n}=7,175)$, had a postgraduate education.

Spouses with this arrangement had an average age of 54.8 years $( \pm 14.17)$, with a minimum of 17 and a maximum of 94 years, and $83.92 \%$ $(n=1,637,385)$ were women. In terms of ethnicity, $48.13 \%(\mathrm{n}=939,035)$ considered themselves Caucasian; $44.05 \%$ ( $n=859,436$ ), mixed race; $6.66 \%$ ( $n=129,991)$, Afro-Brazilian; 0.87\% $(n=16,960)$, Asian-Brazilian; and $0.29 \%(\mathrm{n}=5,673)$, indigenous. In terms of educational level, $70.27 \%(n=1,154,457)$ had a primary level education; $20.31 \%(\mathrm{n}=333,725)$, had a secondary level education; $9 \%(n=147,835)$, had a higher education; and only $0.42 \%(\mathrm{n}=6,828)$, a postgraduate education.

Children of this arrangement had an average age of 23.1 years $( \pm 12.29)$, with a minimum of 0 and a maximum of 67 years, with $51.14 \%$ $(n=1,719,907)$ being male. In terms of ethnicity, 48.13\% ( $\mathrm{n}=939,035)$ considered themselves Caucasian; $44.05 \%$ ( $n=859,436)$, mixed race; $6.66 \%$ $(\mathrm{n}=129,991)$, Afro-Brazilian; 0.87\% ( $\mathrm{n}=16,960)$, Asian-Brazilian; e $0.29 \%(\mathrm{n}=5,673)$, indigenous. The educational level of the offspring was higher than that of their parents: $46.65 \%(n=849,168)$ had a secondary level education; 38.71\% ( $\mathrm{n}=704,493)$, a primary level education; $14.35 \%(\mathrm{n}=261,107)$, superior higher education; and $0.29 \%(\mathrm{n}=5.346)$, a postgraduate education.
The mean age of the other relatives was 33.2 years $( \pm 29.81)$, with a minimum of 0 and a maximum of 109 years, with $54.43 \%(n=1,623,264)$ being women. In terms of ethnicity, $47.08 \%$ $(\mathrm{n}=1,415,974)$ considered themselves Caucasian; $45.45 \%(\mathrm{n}=1,355,559)$, mixed race; $5.90 \%$ $(\mathrm{n}=175,846)$, Afro-Brazilian; 0.89\% $(\mathrm{n}=26,610)$, Asian-Brazilian; $0.21 \%(\mathrm{n}=6,145)$, indigenous; and $0.08 \%(n=2,289)$ not declaring their ethnicity. In terms of level of education, $66.91 \%(\mathrm{n}=757,793)$ had a primary level education; $27.69 \%(\mathrm{n}=313,568)$, a secondary level education; 5.38\% $(\mathrm{n}=60.971)$, a higher education; and only $0.02 \%(\mathrm{n}=221)$, a postgraduate education.

\section{Single-parent}

In single parent families, the mean age of the heads of households was 68.44 years $( \pm 11.47)$, with a minimum of 16 and a maximum of 107 years, with $83.56 \%(n=2,465,021)$ of the heads of households being women. In terms of ethnicity, $47.81 \%(\mathrm{n}=1,410,403)$ considered themselves Caucasian; 41.68\% ( $n=1,229,686)$, mixed race; $9.62 \%(\mathrm{n}=283,731)$, Afro-Brazilian; $0.51 \%(\mathrm{n}=14,964)$, Asian-Brazilian; and $0.38 \%$ $(\mathrm{n}=11,240)$, indigenous. The educational level of the heads of households could be considered low, with $78.68 \%$ ( $\mathrm{n}=1,757,058)$ having only a primary level education.

The mean age of the children from this arrangement was 34.8 years $( \pm 12.85)$, with a minimum of 0 and a maximum of 80 years. A total of $53.33 \%(n=2,289,438)$ of the children were male. In terms of ethnicity, $46.26 \%(n=1,985,881)$ considered themselves mixed race; $44.60 \%$ $(n=1,914,411)$, Caucasian; 8.42\% $(n=361,593)$, Afro-Brazilian; $0.54 \%(\mathrm{n}=22,982)$, Asian-Brazilian; $0.17 \%(\mathrm{n}=7,245)$, indigenous. A total of $0.01 \%$ $(\mathrm{n}=562)$, did not declare their ethnicity. As regards educational level, 47.09\% ( $\mathrm{n}=1,542,849)$ had a primary level education; $37.47 \%(\mathrm{n}=1,227,572)$, a secondary level education; $15.07 \%(\mathrm{n}=493,611)$, a higher education; and $0.38 \%(n=12,454)$, a postgraduate education. 
The mean age of the other relatives was 25.8 years $( \pm 24.06)$, with a minimum of 0 and a maximum of 109 years, with $51.74 \%$ $(\mathrm{n}=1,417,300)$ being male. In terms of ethnicity, $48.41 \%(\mathrm{n}=1,326,106)$ considered themselves mixed race; $42.51 \%(n=1,164,490)$, Caucasian; $8.49 \%(\mathrm{n}=232,554)$, Afro-Brazilian; $0.32 \%$ $(\mathrm{n}=8,734)$, Asian-Brazilian; 0.23\% ( $\mathrm{n}=6,390)$, indigenous; and $0.03 \%(\mathrm{n}=920)$ did not declare their ethnicity. In terms of level of education, $58.41 \%(\mathrm{n}=596,940)$ had a primary level education; $34.63 \%$ ( $\mathrm{n}=353.948$ ), a secondary level education; $6.74 \%(\mathrm{n}=68,830)$, a higher education; and $0.22 \%$ $(n=2,242)$, a postgraduate education.

Couples with children and relatives had younger heads of households (58.8 years), while couples without children had older heads of households (69.3 years), which could be explained by the stage of life in which these individuals find themselves. Only in the lives alone, mixed and single parent arrangements were the heads of households more frequently women. In all the arrangements, the head of household was predominantly Caucasian and the degree of education was primary level. Of the spousal arrangements, younger spouses were found in the couple with children and relatives arrangement (54.8 years), and older spouses in the couple without children arrangement (65.4 years). As with the heads of households, the spouses also declared themselves Caucasian command had a primary level education.

Due to its descriptive nature, the present study contributes important findings for the characterization of household arrangements in which elderly Brazilians are inserted. However, it is necessary to discover whether there is a relationship between the household arrangement to which the elderly person belongs and his or her quality of life.

\section{CONCLUSION}

The predominance of Caucasian ethnicity and the feminization of old age were noticeable, and there was a greater number of older women in relation to men. The education level of the elderly remains low, with most having only a primary level education.

The majority of elderly persons were concentrated in the southeast of the country, especially in the states of São Paulo, Rio de Janeiro and Minas Gerais. Most elderly individuals reside in urban areas, a trend that can be explained by their seeking out services necessary for their requirements in these areas.

The employment rate among the elderly remains low, and of those in work, there was a predominance of males. Ethnicity and place of residence are the variables that most strongly influenced increases in the income of the elderly.

The most representative arrangement was couples who lived with their children and other relatives, followed by single parent arrangements and couples with children. Of the arrangements studied, most were headed by elderly men, except for in sole, single-parent and mixed arrangements, where most of the heads were older women. This situation can be explained by the fact that unlike men, widows or separated women prefer to live with their children, alone or with other relatives than remarry.

However, it is believed that decisions taken by the elderly regarding the type of living arrangement are decisions not only of the elderly persons and their families, but a reflection of a number of historical, socio-cultural, political, economic and demographic factors and may interfere positively or negatively with quality of life.

Households are undergoing changes in, to name just a few characteristics, their constitution, size, arrangement and values. Among these alterations, an important change concerns the situation of elderly members, who in many cases are breadwinners, assuming the role of caregivers instead of being cared for. In this context, future studies should consider a historical and comparative analysis of the reality experienced by elderly residents of a developing country such as Brazil. Such studies can provide useful information on how elderly individuals and families in this country are adjusting to the aging process. 


\section{REFERENCES}

1. Pereira RS, Curioni CC, Veras R. Perfil demográfico da população idosa no Brasil e no Rio de Janeiro em 2002. Textos Envelhecimento 2003;6(1):43-59.

2. Wong LLR, Carvalho JA. O rápido processo de envelhecimento populacional do Brasil: sérios desafios para as políticas públicas. Rev Bras Est Popul 2006;23(1):5-26.

3. Baldoni AO, Pereira LRL. O impacto do envelhecimento populacional brasileiro para o sistema de saúde sob a óptica da farmacoepidemiologia: uma revisão narrativa. Rev Cienc Farm Básica Apl 2011;32(3):313-21.

4. Veras R. Envelhecimento populacional contemporâneo: demandas, desafios e inovações. Rev Saúde Pública 2009;43(3):548-54.

5. Instituto Brasileiro de Geografia e Estatística. Perfil dos idosos responsáveis pelos domicílios no Brasil 2000. Rio de Janeiro: IBGE; 2002.

6. Instituto Brasileiro de Geografia e Estatística. Indicadores sociais municipais: uma análise dos resultados do universo do Censo Demográfico 2010. Rio de Janeiro: IBGE; 2010.

7. Berquó E, Baeninger R. Os idosos no Brasil: considerações demográficas [Internet]. Campinas: UNICAMP; 2000 [acesso em 10 FEV.2014]. Disponível em: http://www.nepo.unicamp.br/textos/ publicacoes/textos_nepo/textos_nepo_37.pdf

8. Camargos MCS. Enfim só: um olhar sobre o universo de pessoas idosas que moram sozinhas no município de Belo Horizonte (MG), 2007 [tese]. Belo Horizonte: Universidade Federal de Minas Gerais, Faculdade de Ciências Econômicas; 2008.

9. Instituto Brasileiro de Geografia e Estatística. Indicadores Sociais Municipais: uma análise dos resultados do Censo Demográfico 2010. Rio de Janeiro: IBGE; 2011. (Estudos e Pesquisas); ( Informação Demográfica e Socioeconômica, n. 28).

10. Camarano AA, Kanso S, Mello JL. Como vive o idoso brasileiro? In: Camarano AA, organizadora. Os novos idosos brasileiros, muito além dos 60? Rio de Janeiro: IPEA; 2004. p. 25-73.

11. Parahyba MI, Veras R. Diferenciais sociodemográficos no declínio funcional em mobilidade física entre os idosos no Brasil. Ciênc Saúde Coletiva 2008;13(4):1257-64.
12. Instituto Brasileiro de Geografia e Estatística. Pesquisa Nacional por Amostra de Domicílios: Síntese de Indicadores 2012. Rio de Janeiro: IBGE; 2013.

13. Medri W. Análise exploratória de dados. Londrina: Universidade Estadual de Londrina; 2011.

14. Nishi LF. Coeficiente de Gini: uma medida de distribuição de renda. Florianópolis: Universidade do Estado de Santa Catarina; 2010

15. Neri M. Curva de Lorenz [Internet]. Rio de Janeiro: Fundação Getúlio Vargas; 2010 [acesso em 10 fev. 2014]. Disponível em: http://www.cps.fgv.br/cps/ pesquisas/ Politicas_sociais_alunos/2010/BES_raiz_ aanew/pdf/sbst/BES_CurvadeLorenz.pdf

16. Fávero LP. Métodos quantitativos com Stata. Rio de Janeiro: Elsevier; 2014.

17. Ramos JLC, Menezes MR, Meira EC. Idosos que moram sozinhos: desafios e potencialidades do cotidiano. Rev Baiana Enferm 2010;24(1):43-54.

18. Santos TS. Gênero e políticas sociais: novos condicionamentos sobre a estrutura familiar. SER Soc 2008;10(22):97-128.

19. Camarano AA. Mulher idosa: suporte familiar ou agente de mudança? Estud Av 2003;17(49):35-63.

20. Goldani AM. As famílias brasileiras: mudanças e perspectivas. Cad Pesqui 1994;91:7-22.

21. Instituto Brasileiro de Geografia e Estatística. Síntese de indicadores sociais: Uma análise das condições de vida da população brasileira - 2012. Rio de Janeiro: IBGE; 2012. (Estudos e Pesquisas) ; (Informação Demográfica e Socioeconômica, n. 29)

22. Melo NCV, Teixeira KMD, Ferreira MAM, Silva NM. Perfil socioeconômico do consumidor idoso nos arranjos familiares unipessoal e residindo com o cônjuge: uma análise de dados da Pesquisa de Orçamentos Familiares (2008/2009). Soc Debate 2014;20(2):216-37.

23. Queiroz VS, Ramalho HMB, Monte PA. A inserção do idoso no mercado de trabalho: evidências a partir da duração do desemprego no Brasil. In: $17^{\circ}$ Encontro Regional de Economia; 2012; Fortaleza. Fortaleza: BNB/ANPEC; 2012.

24. Melo NCV, Teixeira KMD, Ferreira MAM, Silva, NM. Consumo por idosos nos arranjos familiares "unipessoal" e "residindo com o cônjuge": uma análise por regiões do país a partir dos dados da POF (2008/2009). Rev Bras Geriatr Gerontol 2014;17(4):841-52. 